\title{
High Efficiency of Muscle Regeneration after Human Myoblast Clone Transplantation in SCID Mice
}

\author{
Johnny Huard, Steeve Verreault, Raynald Roy, * Martine Tremblay, and Jacques P. Tremblay \\ Centre de recherche en Neurobiologie, Hôpital de l'Enfant-Jésus, Québec, Canada G1J 1Z4; and *Centre de Recherche en Inflammation, \\ Immunologie et Rhumatologie, Le Centre Hospitalier de l'Université Laval, Ste-Foy, Québec, Canada GIV 4G2
}

\begin{abstract}
SCID mouse tibialis anterior muscles were first irradiated to prevent regeneration by host myoblasts and injected with notexin to damage the muscle fibers and trigger regeneration. The muscles were then injected with roughly 5 million human myoblasts. 1 mo later, 16-33\% of the normal number of muscle fibers were present in the injected muscle, because of incomplete regeneration. However, $>\mathbf{9 0} \%$ of these muscle fibers contained human dystrophin. Some newly formed muscle fibers had an accumulation of human dystrophin and desmin on a part of their membrane. Such accumulations have been demonstrated at neuromuscular junctions before suggesting that the new muscle fibers are innervated and functional. The same pool of clones of human myoblasts produced only $\leq 4 \%$ of muscle fibers containing human dystrophin when injected in nude mice muscles.

Several of the human myoblasts did not fuse and remained in interstial space or tightly associated with muscle fibers suggesting that some of them have formed satellite cells. Moreover, cultures of $98 \%$ pure human myoblasts were obtained from transplanted SCID muscles. In some mice where the muscle regeneration was not complete, the muscle fibers containing human dystrophin also expressed uniformly HLA class 1, confirming that the fibers are of human origin. The presence of hybrid muscle fibers containing human dystrophin and mouse MHC was also demonstrated following transplantation.

These results establish that in absence of an immune reaction, transplanted human myoblasts participate to the muscle regeneration with a high degree of efficacy even if the animals were killed only 1 mo after the transplantation. (J. Clin. Invest. 1994. 93:586-599.) Key words: muscular dystrophy • mouse • immunity • transplantation immunology • muscles
\end{abstract}

\section{Introduction}

Duchenne muscular dystrophy (DMD) ${ }^{1}$ is a muscle pathology characterized by a genetic alteration in $\mathrm{Xp} 21$ locus causing a lack of dystrophin expression (1-9). This protein has been localized under the sarcolemma and may be involved in main-

Address correspondence to Dr. Jacques P. Tremblay, Centre de Recherche en Neurobiologie, Hôpital de l'Enfant-Jésus, 1401, 18e Rue, Québec, Canada G1J 1Z4.

Received for publication 26 March 1993 and in revised form 4 October 1993.

1. Abbreviations used in this paper: DMD, Duchenne muscular dystrophy; HLA, human leukocyte antigen; RT-PCR, reverse transcription PCR; TA, tibialis anterior.

J. Clin. Invest.

(C) The American Society for Clinical Investigation, Inc.

$0021-9738 / 94 / 02 / 0586 / 14 \$ 2.00$

Volume 93, February 1994, 586-599 taining the integrity of the muscle membrane $(4,10-13)$. The mdx mice possess a genetic alteration in the same locus, causing an absence of dystrophin expression $(3,5,7,9)$. Thus, this is a good biochemical model for DMD. Myoblast transplantation is one possible strategy to restore dystrophin in DMD patients. Several reports showed this procedure restored dystrophin in mdx mice (14-21). Other studies suggested that myoblast transplantation also improved the physiology and structure of dystrophic mouse $\left(\mathrm{dy}^{2 \mathrm{~J}} / \mathrm{dy}^{2 \mathrm{~J}}\right)$ injected muscles (22). The highest percentage of dystrophin positive fibers after myoblast transplantation was obtained by Partridge team in immunodeficient nude mdx mice (17), suggesting that the immune system interferes with the process. Our results demonstrated that human myoblasts transplanted in $\mathrm{mdx}$ mice that were not adequately immunosuppressed triggered an immune reaction that led to myoblast rejection. In several of these $\mathrm{mdx}$ mice, humoral and cellular immune reactions were induced by human myoblast transplantation (14).

Several research groups have performed myoblast transplantations in DMD patients with little success (23-27), likely caused by the same type of immune system interference found in mdx mice. Even when immunosuppressive treatments were used (cyclosporine A or cyclophosphamide), the success of myoblast transplantation in DMD patients was limited $(23,25$, 26). In our laboratory, we have transplanted nine DMD patients using immunocompatible donors for the HLA class I and II Dr. After such myoblast transplantations, several DMD patients expressed dystrophin in the injected skeletal muscle, and some presented an increase of strength that decayed over time (probably because of a slow rejection process) $(24,27)$. Our results suggest that the humoral immune reaction is directed against dystrophin and its associated proteins, as well as other unknown antigens (28).

The purpose of the present study was to evaluate the regenerative capacity of human myoblast clones in animals with compromised immune systems (SCID and nude mice). This study also aims to verify whether clones of human myoblasts that have been intensively proliferated in vitro can form mature muscle fibers.

\section{Methods}

Animals. The animals used in these experiments are the immunodeficient BALB/C SCID (Jackson Lab, Bar Harbor, ME) and CD1 nude mice (Charles River Canada, Montréal, Canada). 10 SCID and 10 nude mice $\sim 1$ mo old were used. This work was authorized and supervised by Laval University Animal Care Committee and was conducted in accordance to the guidelines set by the Canadian Council of Animal Care.

Preparation of human myoblasts. Human myoblasts were obtained from a postmortem biopsy. The procedure of myoblast cloning was previously described (29). Briefly, the clones are obtained by limiting dilution. After the cell proliferation of up to 1 million myoblasts per clone, a sample of $\sim 100,000$ cells was tested by flowcytometry to 
verify the presence of neural cell adhesion molecule. Only the clones that were more than $95 \%$ neural cell adhesion molecule positive were considered myoblast clones and kept for transplantation. A pool of 20 human myoblast clones, each containing more than 1 million cells, was constituted and further expended in a proliferating medium $\operatorname{MCDB} 120(29,30) 4 \mathrm{~d}$ before transplantation. More than 200 million myoblasts were produced from this pool. The day of transplantation, the myoblasts were detached with $0.1 \%$ trypsin and washed several times in HBSS. Pellets of human myoblasts were obtained by centrifugation. Each pellet containing $\sim 10$ million myoblasts was resuspended in $10 \mu \mathrm{l}$ of PBS.

Myoblast transplantation. $4 \mathrm{~d}$ before transplantation, the left posterior leg of each mouse was irradiated with 20 grays of gamma rays to block proliferation of endogenous myogenic cells. $3 \mathrm{~d}$ later, the tibialis anterior (TA) of the irradiated leg was destroyed with $10 \mu \mathrm{l}$ of snake venom (notexin) at a concentration of $10 \mu \mathrm{g} / \mathrm{ml}$. This toxin specifically damages muscle fibers $(31)$. The next day, $\sim 5$ million human myoblasts were transplanted in 8-10 sites of this TA. 5 million human myoblasts were reinjected in the same muscle $10 \mathrm{~d}$ later. The injection of myoblasts was done using a disposable micropipette (Wiretrol, $10 \mu \mathrm{l}$; Drummond Scientific Co., Broomall, PA). This small glass micropipette was pulled with a pipette puller and the tip was broken at $\sim 70$ $90 \mu \mathrm{m}$.

Muscle biopsy and dystrophin detection by immunohistochemistry. 10 or $30 \mathrm{~d}$ after the first transplantation, these mice were perfused with $0.9 \% \mathrm{NaCl}$ under deep anesthesia produced by $0.05 \mathrm{ml}$ of $10 \mathrm{mg} / \mathrm{ml}$ ketamine and $10 \mathrm{mg} / \mathrm{ml}$ xylasine. The blood and the tibialis anterior muscles were kept for analysis. The blood was centrifuged and the serum was kept at $-20^{\circ} \mathrm{C}$ for cytofluorometric analysis. The muscles were frozen in liquid nitrogen. Serial 8- $\mu \mathrm{m}$ cryostat sections were obtained throughout the muscles, and human dystrophin was detected at every 10 sections by an immunoperoxidase technique using the NCLDys 3 monoclonal antibody (32). The sections were incubated $2 \mathrm{~h}$ with NCLDys3 (dilution 1/40; Novocastra, New Castle Upon Tyne, United Kingdom). After rinses, the sections were incubated with a rabbit antimouse antibody coupled with peroxidase (Dako, Glostrup, Denmark). The peroxidase activity was revealed with diaminobenzidine $(0.5 \mathrm{mg} / \mathrm{ml})$ and hydrogen peroxide $(0.015 \%)$.

Dystrophin detection by PCR. The presence of human dystrophin in a myoblast /myotube culture obtained from a biopsy of a myoblastinjected muscle was detected by PCR. RNA was extracted using the method of Chomczynski and Sacchi (33). A sample of $500 \mathrm{ng}$ of RNA was amplified using the primers DMD2a and DMD2b described by Roberts et al. (34). Primer DMD2a corresponds to nucleotides 10911111 of human dystrophin mRNA (seq. 5' to $3^{\prime}$ : CGATTCAAGAGCTATGCCTAC). Primers DMD2b corresponds to nucleotides 23992419 (seq. 5' to 3': GCGAGTAATCCAGCTGTGAAG). These primers amplify exons 9-18 (nucleotides number 1091-2419) of human dystrophin, but we found that they did not amplify mouse dystrophin. The amplification was performed as described by Roberts et al. (34).

Detection of HLA class 1 . HLA class 1 antigens were detected using a monoclonal antibody (W6/32; American Type Culture Collection, Rockville, MD) conjugated with FITC. The muscle sections were incubated for $1 \mathrm{~h}$ with a blocking solution containing $3 \%$ rabbit, $3 \%$ calf, and $3 \%$ horse sera. After a rinse in $0.1 \mathrm{M}$ phosphate buffer, $\mathrm{pH} 7.4$, containing $0.45 \%$ sodium chloride, these sections were incubated with the W6/32 antibody $(1 / 40)$ with $1 \%$ blocking serum for $1 \mathrm{~h}$. These specimens were observed with an epifluorescence microscope after several rinses in PBS.

Detection of mouse antibodies against human myoblasts. Blood was collected when the recipient animals were killed. The presence of antibodies against the human myoblasts was evaluated by cytofluorometric analysis. This analysis was done as follows: $(a)$ Human myoblast suspensions $\left(2 \times 10^{5}\right.$ cells $)$ were washed in PBS and resuspended in $40 \mu \mathrm{l}$ of PBS and $20 \mu \mathrm{l}$ of the mouse serum was added. (b) After incubation at room temperature for $30 \mathrm{~min}$, the cells were washed in 4 $\mathrm{ml}$ of PBS, and the cell pellet was resuspended in $100 \mu \mathrm{l}$ of 1:20 dilution of FITC-conjugated anti-mouse IgG (Coulter Immunology Hialeah,
$\mathrm{FL}) .\left(\right.$ c) The cells were incubated for an additional $30 \mathrm{~min}$ at $4^{\circ} \mathrm{C}$ and washed in PBS solution. $(d)$ The cells were then immediately analyzed for the percentage of fluorescence with cytofluorometer (Epics; Coulter Corp.) operated at $488 \mathrm{~nm}$.

Detection of desmin by immunofluorescence. The sections were incubated overnight with a mouse monoclonal antibody against human desmin (Dako) dilution $1 / 75$ in PBS with $1 \%$ blocking serum (a mixture of horse, rabbit, and calf serum). After three rinses in PBS, the sections were incubated with a rabbit antimouse antibody coupled to FITC (dilution 1/100; Dako).

\section{Results}

Regeneration in SCID muscles. The TA muscles of SCID and nude mice were destructed with notexin and irradiated to prevent regeneration. They were then injected with $\sim 5$ million human myoblasts. In initial preliminary experiments, the animals were killed $10 \mathrm{~d}$ after the transplantation. The presence of human dystrophin was detected on cryostat sections throughout the injected SCID muscles using a monoclonal antibody specific for human dystrophin (NCLDys3) (32). Although the contralateral noninjected muscles contained mouse dystrophin, they were always completely devoid of immunoreactivity, showing the high specificity of antibody against human dystrophin (Fig. $1 a$ ).

The tibialis anterior of SCID mice, which had been previously irradiated, destroyed with notexin, and injected with human myoblasts, expressed the human dystrophin in several muscle fibers (Fig. 1, $b$ and $c$ ). In these injected muscles, the diameter of human dystrophin positive muscle fibers was not uniform and several injected muscles contained a lot of small muscle fibers expressing human dystrophin. Such results may indicate ongoing muscle regeneration. Most of the animals in the present experience were, therefore, killed at a longer interval (30 d) after the myoblast transplantation. Several areas of some injected muscles were still devoid of muscle fibers and, instead, contained connective and adipose tissues (Fig. $2 a$ ). The number of human dystrophin positive and human dystrophin negative fibers were counted in myoblast injected and control muscles for the animals killed at $30 \mathrm{~d}$ after the first of two myoblast injections (Table I). (It should be noted that in the contralateral control muscle, the number of human dystrophin positive fibers in always zero because of the specificity of the antibody.) The diameter of the myoblast injected muscle is always less than that of the control muscle for several reasons: (a) The total number of muscle fibers is $\sim 30 \%$ of that of a normal muscle; $(b)$ the diameter of these fibers is reduced; and (c) the muscle was taken only $30 \mathrm{~d}$ after the first myoblast injection. In other areas, muscle fiber diameter varied greatly showing that muscle regeneration may continue even 1 mo after transplantation (Fig. 2, $b$ and $c$ ). However, in several SCID mouse muscles, $>90 \%$ of fibers contained human dystrophin. These more advanced regenerations were obtained when the TA muscle was injected with human myoblasts at several sites, and when the same muscle was again destroyed with notexin and reinjected with human myoblasts $1 \mathrm{wk}$ later (Fig. $2 d$ ).

Presence of NMJs on regenerated fibers. Fig. 3 illustrates several injected muscles of SCID mice at high magnification. The intensity of the human dystrophin immunoreaction was not uniform (Fig. 3, $a-d$ ). While human dystrophin was uniformly present in the sarcolemma of a most muscle fibers, in some muscle fibers a part of the membrane perimeter con- 

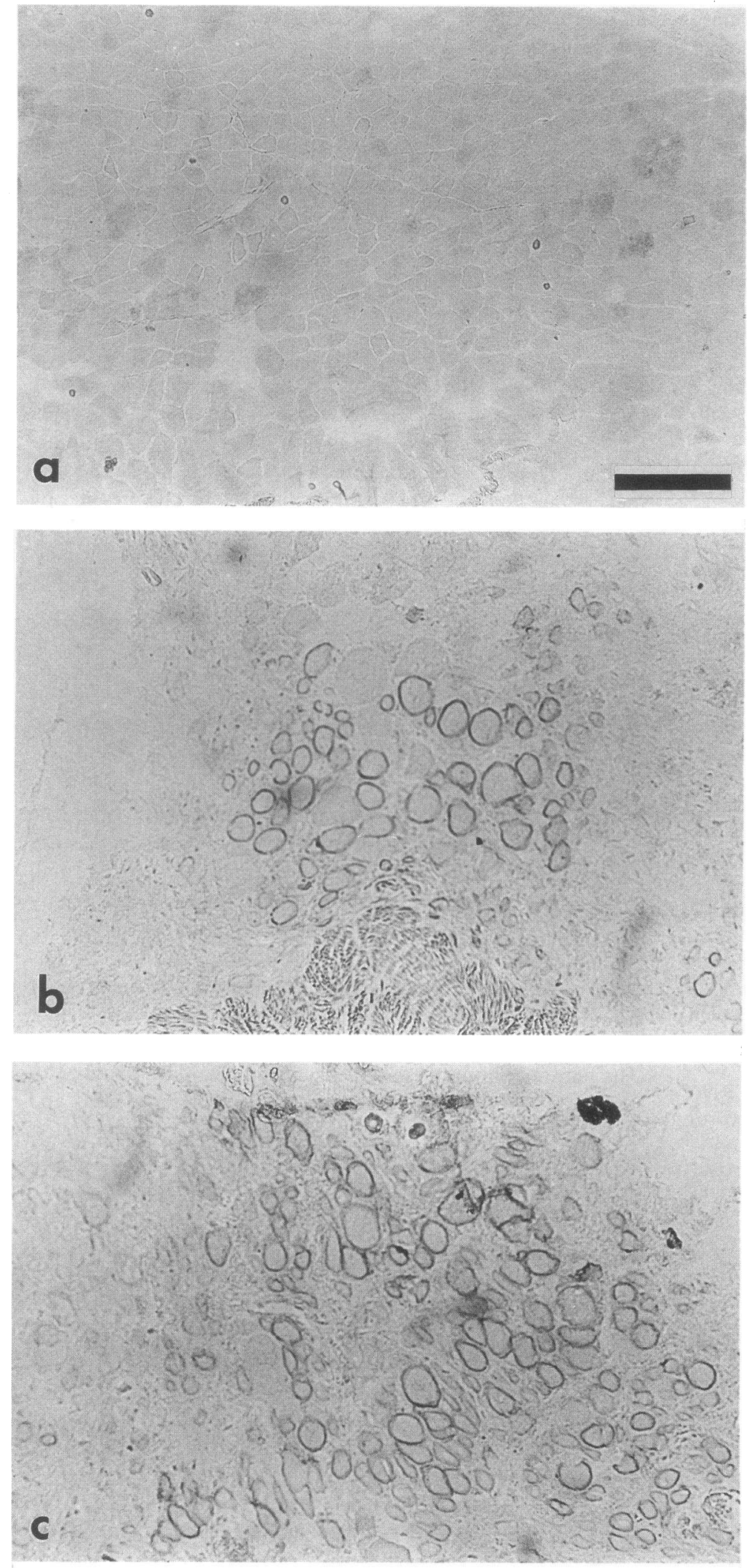

Figure 1. (a) Control contralateral muscle of a SCID mouse not injected with human myoblasts. No fiber containing human dystrophin is present. ( $b$ and $c$ ) SCID muscles injected $10 \mathrm{~d}$ before with 5 million human myoblasts. Numerous muscle fibers of variable sizes expressed human dystrophin detected by immunoperoxidase with the NCLDys3 antibody. Bars, $50 \mu \mathrm{m}$. tained a higher concentration of human dystrophin (Fig. $3 c$ ). There was a more intense desmin immunoreactivity at the site of dystrophin accumulation (Fig. 4, $a$ and $b$ ).

Less efficient regeneration in nude mice. The same clones of human myoblasts were also transplanted in nude rather than SCID mice. This also produced several muscle fibers express- ing human dystrophin. However, in nude mice, the injection of human myoblasts never produced a very high percentage of muscle fibers expressing human dystrophin (Fig. 5, $a$ and $c$, and Table I). The noninjected nude and SCID muscles were devoid of immunostaining for human dystrophin (Fig. 5, $b$ and d). 

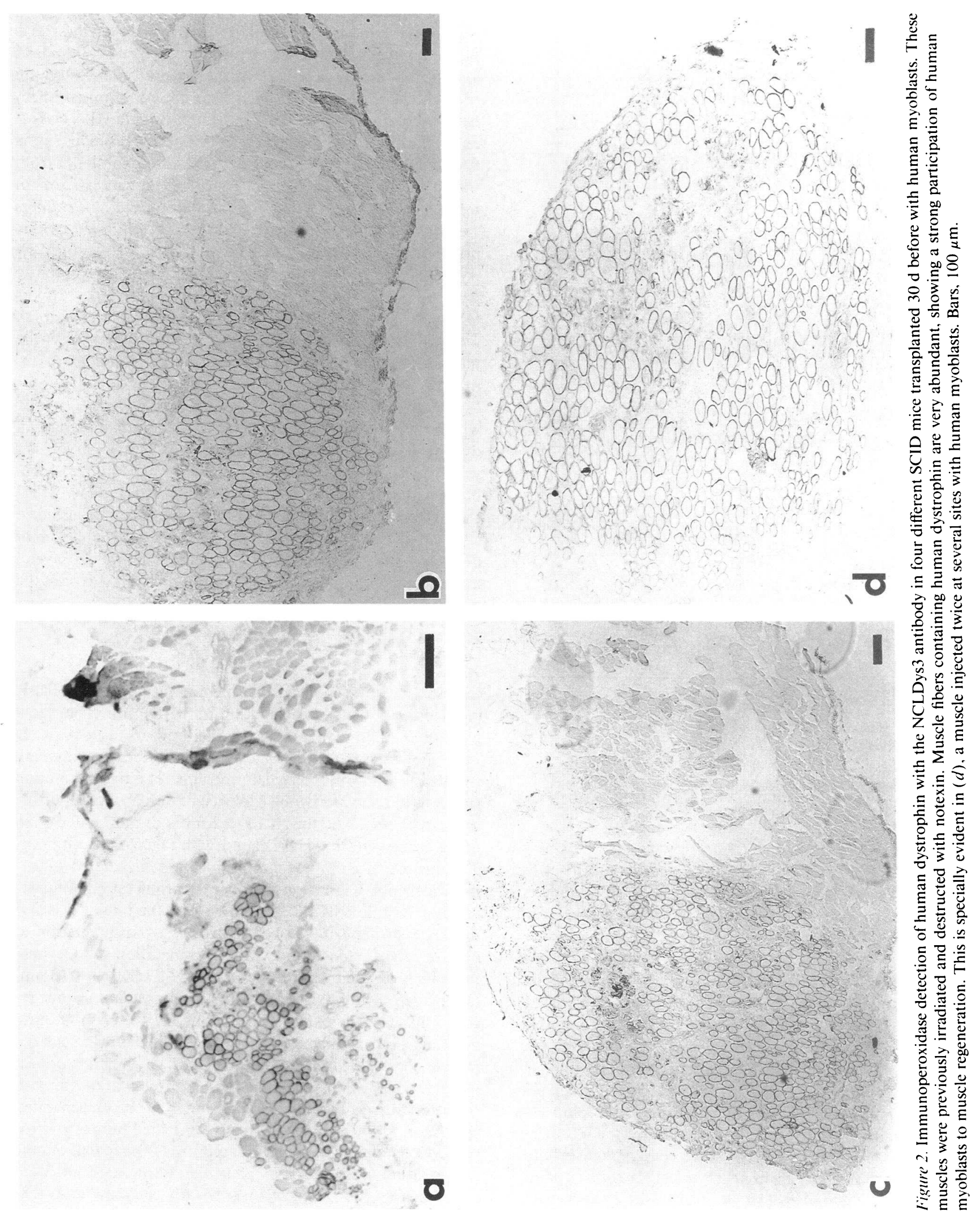
Table I. Comparative Results of Human Myoblast

Transplantation in SCID and Nude Mice

\begin{tabular}{|c|c|c|c|c|c|c|}
\hline \multirow{2}{*}{$\begin{array}{l}\text { Host } \\
\text { strain }\end{array}$} & \multirow[b]{2}{*}{ Muscle } & & \multirow{2}{*}{$\begin{array}{l}\text { Total } \\
\text { number } \\
\text { of fibers }\end{array}$} & \multicolumn{2}{|c|}{$\begin{array}{c}\text { Human } \\
\text { dystrophin- } \\
\text { positive muscle } \\
\text { fibers }\end{array}$} & \multirow{2}{*}{$\begin{array}{c}\text { Cytometric } \\
\text { analysis }\end{array}$} \\
\hline & & & & Number & Percent & \\
\hline \multirow[t]{13}{*}{ SCID mice } & Not grafted & 1 & 852 & 0 & 0 & \\
\hline & & 2 & 1,757 & 0 & 0 & \\
\hline & & 3 & 1,189 & 0 & 0 & \\
\hline & & 4 & 2,648 & 0 & 0 & \\
\hline & Grafted & 1 & 276 & 216 & 78.2 & - \\
\hline & & 2 & 273 & 262 & 95.9 & - \\
\hline & & 3 & 390 & 385 & 98.7 & - \\
\hline & & 4 & 592 & 543 & 91.7 & - \\
\hline & & 5 & 560 & 548 & 97.8 & - \\
\hline & & 6 & 580 & 569 & 98.1 & - \\
\hline & & 7 & 570 & 500 & 87.7 & - \\
\hline & & 8 & 635 & 600 & 94.4 & - \\
\hline & & 9 & 640 & 595 & 92.9 & - \\
\hline \multirow[t]{10}{*}{ Nude mice } & Not grafted & 1 & 1,697 & 0 & 0 & \\
\hline & & 2 & 1,908 & 0 & 0 & \\
\hline & & 3 & 1,985 & 0 & 0 & \\
\hline & & 4 & 2,074 & 0 & 0 & \\
\hline & & 5 & 1,704 & 0 & 0 & \\
\hline & Grafted & 1 & 1,517 & 46 & 3 & - \\
\hline & & 2 & 2,125 & 18 & 0.8 & + \\
\hline & & 3 & 1,642 & 41 & 2.49 & - \\
\hline & & 4 & 1,886 & 23 & 1.21 & + \\
\hline & & 5 & 1,601 & 58 & 3.6 & - \\
\hline
\end{tabular}

The total number of muscle fibers in a cross-section of the TA muscle were counted. The number of muscle fibers expressing human dystrophin was also counted and expressed as a percent of the total number of fibers. The presence in the recipients' sera of antibodies against the donors' myoblasts was determined by flow cytometry.

The sera of the nude and SCID mice were kept to check for antibodies against the human myoblasts by cytofluorometry. None of the SCID mice had such antibodies. However, two out of five nude mice did (Table I).

Fate of human myoblasts. The fate of human myoblasts was monitored by a monoclonal antibody (W6/32) against human leukocyte antigens (HLA) class 1 . Cryostat sections of untreated SCID mouse muscles were completely devoid of immunoreactivity for HLA class 1 (Fig. $6 a$ ). The same was true for nude mice (not illustrated). However, in SCID mice injected with human myoblasts, the muscles that had a high percentage of muscle fibers containing human dystrophin also contained many small cells immunoreactive for the HLA class I (Fig. $6 b$ ). These small HLA-positive cells were distributed between muscle fibers in the myoblast injected region or tightly associated with these fibers (Fig. 6, $b$ and $d$ ). However, when the injected muscle was less regenerated (i.e., the muscle fibers containing human dystrophin were still dispersed in fat and connective tissue), all fibers expressing human dystrophin (Fig. 7, $a-c$ ) also expressed HLA class 1 (Fig. 7, b-d). The HLA immunolabeling was then uniformly distributed on the sarcolemma of immature muscle fibers (Figs. $6 c$ and $7 b-d$ ). There were also a few small cells expressing HLA class 1 , but not expressing human dystrophin (Fig. 7, $b-d$ ). These small cells are myoblasts or small myotubes. Pieces of the transplanted muscles were dissociated with trypsin and collagenase, and the dissociated cells were placed in culture. The cells were proliferated $>10,000$-fold. They were then trypsinised, incubated with an antibody (W6/32) against human HLA class 1, and found by flowcytometry to be $98 \%$ HLA positive (Fig. 8 $b$ ). Myotubes were also present in these cultures obtained from transplanted muscles. The presence of human dystrophin mRNA was demonstrated by PCR amplification using primers specific for human dystrophin (Fig. $8 a$ ). These human specific primers (primers DMD 2a and DMD 2b) were identified by trying to amplify mouse dystrophin mRNA with each of the 24 pairs of primers described by Roberts et al. (34). Primers DMD 2a and DMD 2b were completely unable to amplify mouse dystrophin, but amplified human dystrophin present in the culture made from mouse muscles transplanted with human myoblasts.

Presence of hybrid (human-mouse) muscle fibers. To verify whether the regenerated muscle fibers that contained human dystrophin were formed by the fusion of $(a)$ human myoblasts with partially degenerated mouse fibers or $(b)$ human myoblasts with one another, human dystrophin and mouse MHC class $\mathrm{I}$ antigen (i.e., $\mathrm{H}^{2 \mathrm{~d}}$ in BALB/c mice) were localized in adjacent sections. There were a few hybrid muscle fibers that expressed both antigens (Fig. 9, $a$ and $b$ ). However, several muscle fibers containing human dystrophin did not express the mouse MHC antigen (Fig. 9, $c$ and $d$ ).

\section{Discussion}

In absence of immunological problem, transplanted myoblasts participate to muscle regeneration in SCID mice. The transplantation of human myoblasts in immunodeficient SCID mice allowed us to demonstrate the efficacy of this treatment in the absence of immunological problems. The transplantation success was analyzed by the presence of human dystrophin in injected muscles with the NCLDys 3 antibody and by detection of the cells expressing HLA class 1 with the W6/32 antibody. The muscles of immunodeficient mice were irradiated $4 \mathrm{~d}$ before the myoblast injection to reduce the proliferation of endogenous myogenic cells $(17,25)$. Moreover, the muscle was also injected with notexin $1 \mathrm{~d}$ before myoblast transplantation to damage muscle fibers and trigger regeneration (31). These treatments allowed us to reproduce a DMD-like muscle containing degenerating muscle fibers with a poor autologous regenerative capacity. After such treatments, muscles that were not transplanted with myoblasts decreased in diameter, and the muscle fibers were rapidly replaced ( $2 \mathrm{wk}$ ) by fat and connective tissue. However, after myoblast transplantation, fat and connective tissue were far less abundant in the best regenerated muscle and $>90 \%$ of muscle fibers contained human dystrophin, while muscle diameter reduced to $\sim 30 \%$ of that of normal muscles. It should be emphasized that these results were obtained only $1 \mathrm{mo}$ after the myoblast transplantation. At that time, the muscle still contained many small muscle fibers, which suggests that the regeneration process was still ongoing. These small muscle fibers will presumably increase their diameter with time. New experiments are underway to evaluate the long-term (6-12 mo) results of myoblast transplantation in 

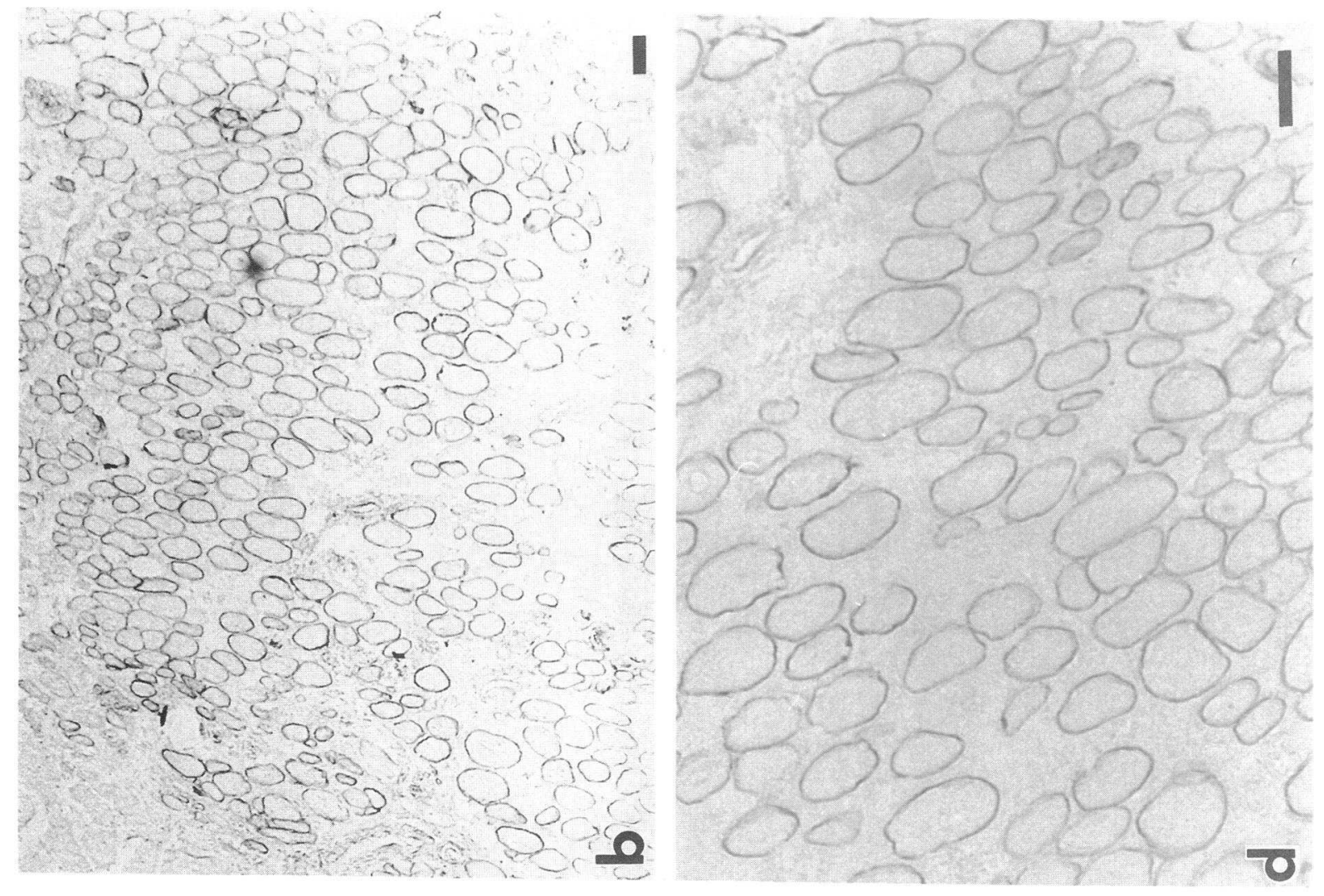

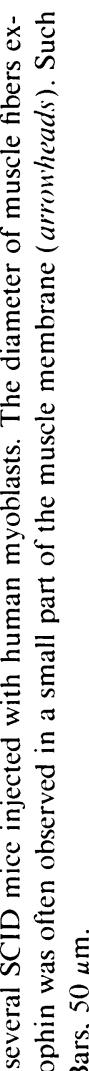

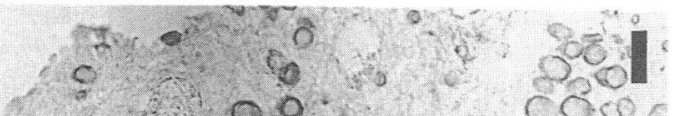
10.0 .0 .000

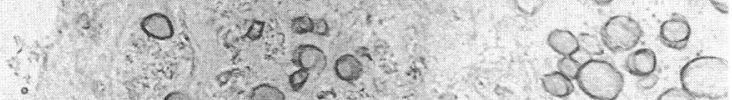

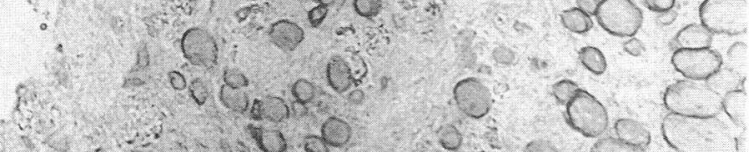

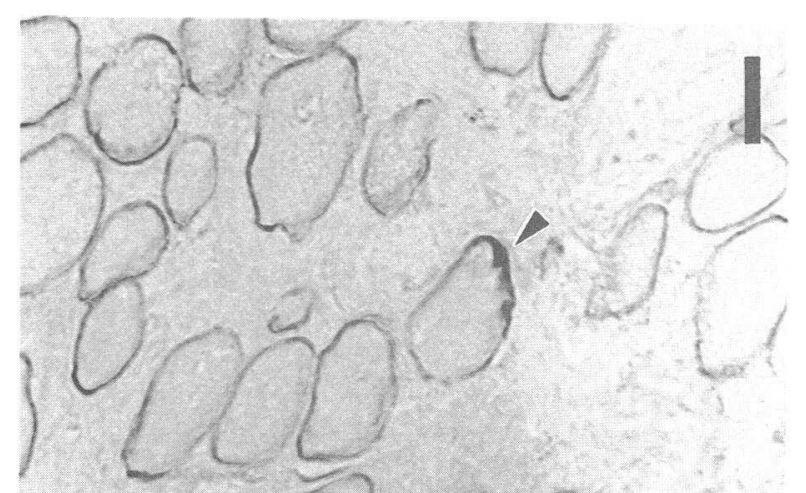

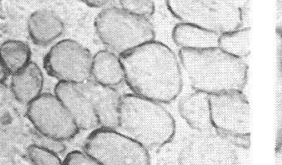

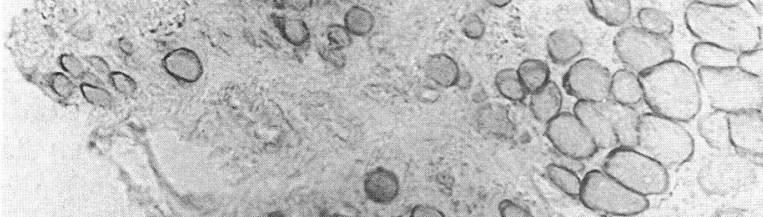

- jacroa onoto

* aro a ofma

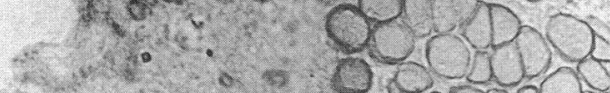

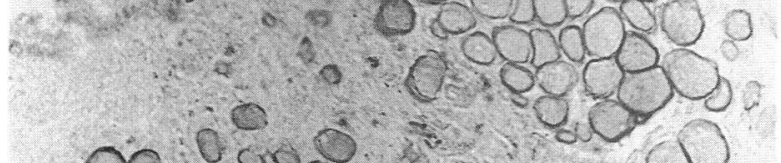

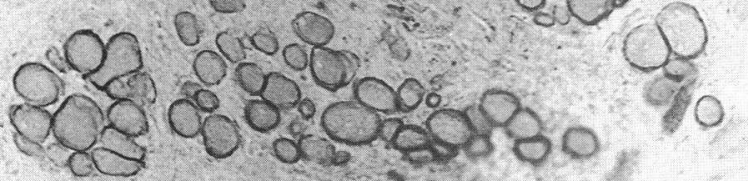
ats
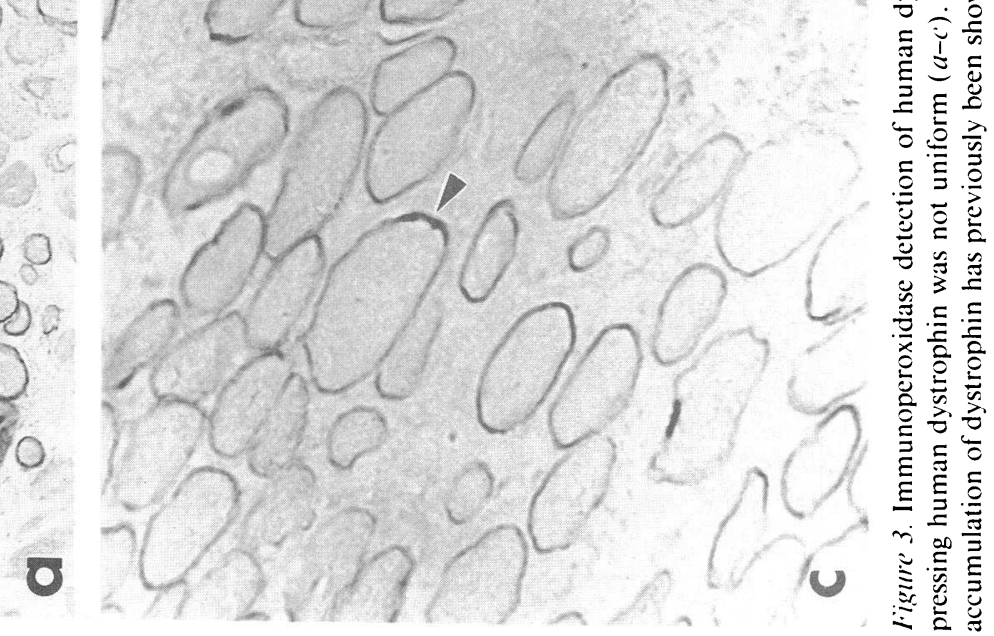

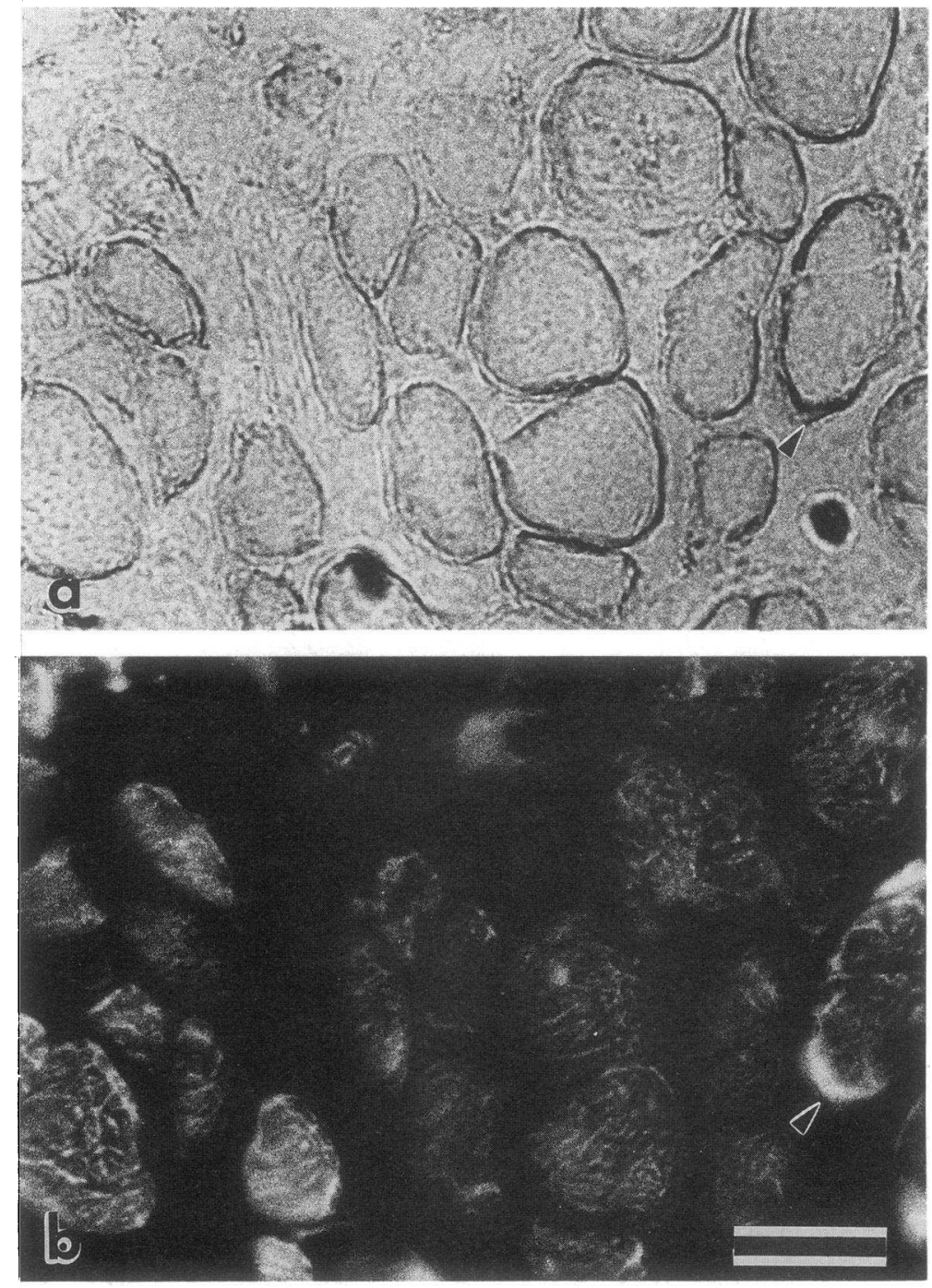

Figure 4. This figure illustrates an accumulation of human dystrophin by immunoperoxidase $(a)$ and of desmin by immunofluorescence $(b)$ at exactly the same site (arrow) on a regenerated muscle fiber. Scale bars, $50 \mu \mathrm{m}$.
SCID. The cytofluorometry analysis revealed a complete absence of antibodies against human myoblasts in these SCID mice.

In nude mice, the participation of human myoblast to muscle regeneration is less important. Our previous experiments have shown that when human myoblast clones were transplanted in immunocompetent mdx mice without immunosuppression they did not participate to muscle regeneration (14). There was only a small muscle regeneration when the mice were treated with cyclosporine and/or antilymphocyte serum. However, in the present experiments, as well as in previous experiments $(14,32)$, injection of a pool of human myoblast clones in muscles of nude mice produced some muscle regeneration. Indeed, several muscle fibers expressing human dystrophin were observed in the nude muscles 1 mo after transplantation. However, in two out of five nude mice, antibodies against the human myoblasts were detected by flowcytometry. This is one evidence of an immune reaction that could be responsible for the lack of complete muscle regeneration in nude mice. Nude mice are athymic animals. This absence of thymus prevents the maturation of $\mathrm{T}$ lymphocytes and, therefore, cellular immune reaction. However, nude mice have mature B lymphocytes and are able to sometimes develop a humoral immune reaction that may reduce the efficacy of myoblast transplantation in these mice. This may account for the difficulty that Dr. Partridge's group had obtaining a high level of muscle regeneration even in nude/mdx mice $(19,20)$.

Muscle regeneration is better with several myoblast injections. When injected into notexin-destroyed and irradiated SCID mouse muscles, human myoblasts from the same pool of clones participated more in muscle regeneration (Fig. 1) than in nude mice. Their degree of participation to muscle regeneration varied, although all animals were injected with the same pool of human myoblasts and killed after the same delay. This regeneration variability in SCID mice was partly associated with variations in the damage produced by notexin or the variability of the myoblast injections. However, it was clear that when a muscle was injected only one time at only one site, the degree of muscle regeneration was low, with the fibers containing human dystrophin localized at the injection site still separated by fat and connective tissue 1 mo after myoblast injection. In these muscles, the diameter of the muscle fibers was variable. When the muscle was injected two times with myoblasts at several sites, the muscle regeneration was near complete, there was less fat and connective tissue, and $>90 \%$ of the muscle fibers expressed human dystrophin.

Regenerating muscles: expression of HLA on muscle fibers. When an injected muscle was still regenerating (i.e., presence of fat and muscle fibers of variable size), several muscle fibers expressing human dystrophin on their membranes also ex- 


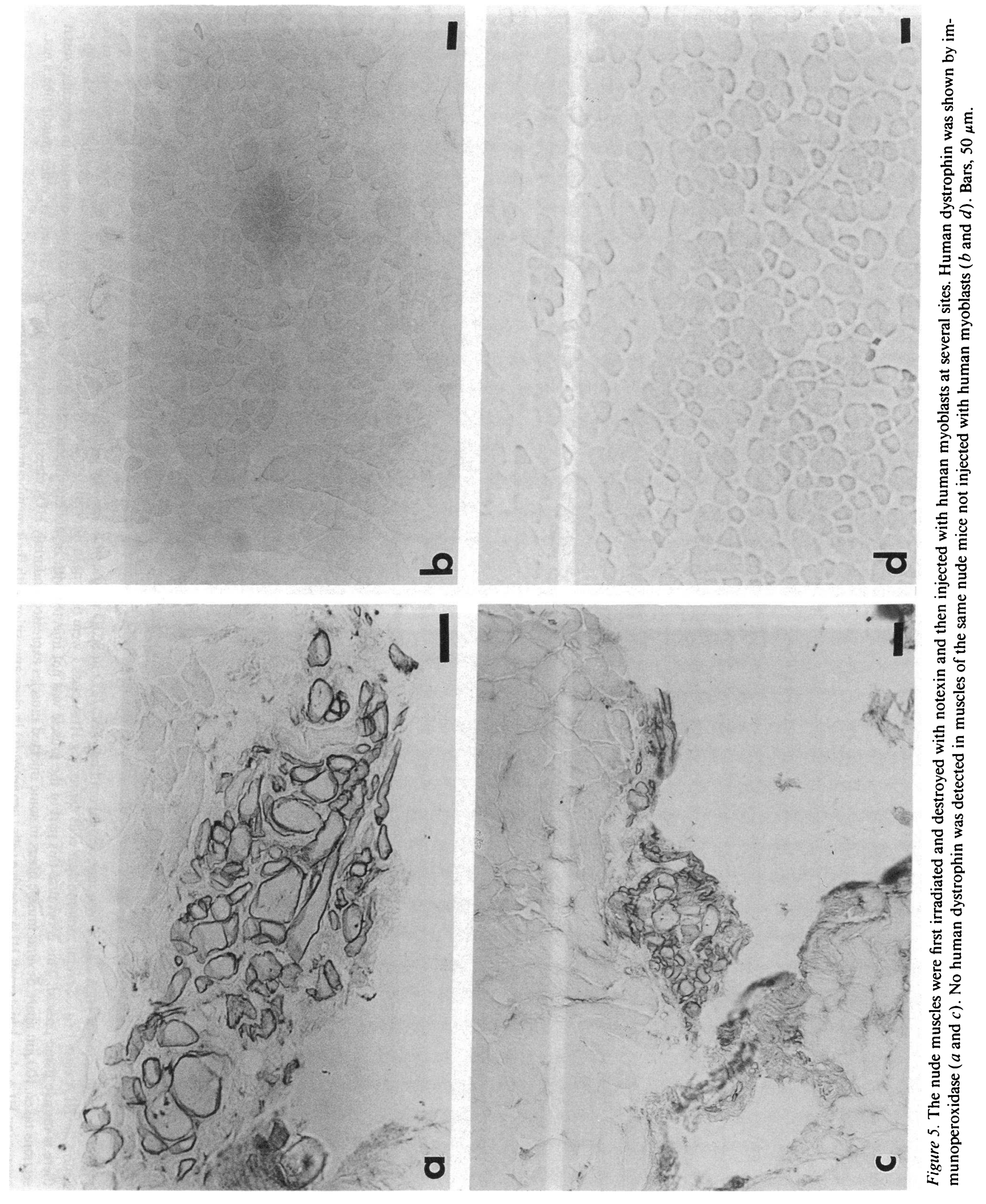




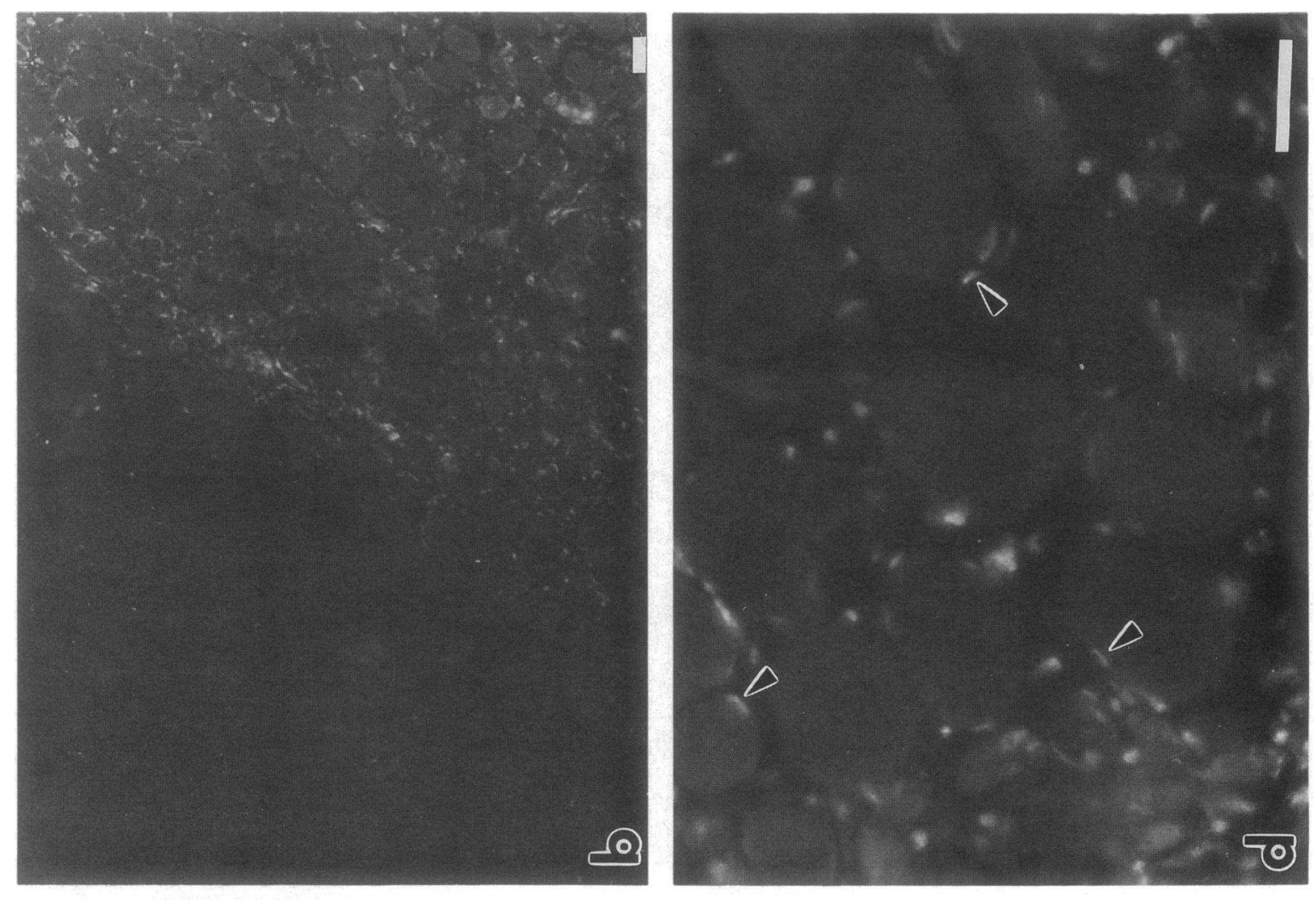

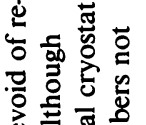

导产 画

궁. 垴品

흘

ह

8 拜

密。

3 要

है

号焉

论

ธ。․ㅠ. 요

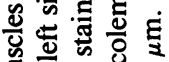
를 政 造运焉 急守 o

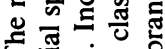
的部 을 尊 घ. $\Xi E$ 岩若焉递 \& 喽 웡 证至 $\Xi \frac{1}{0}$ 的 元密 ल 造造

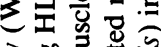
중. o

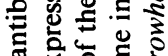

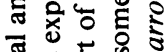
তี 응 छ 记 은 ๙ उิ월 일 级 递要题 $\varangle$

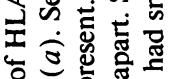
등 。可号

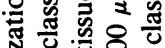
중

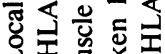
놀 $\circ$ 进 咩 语论 

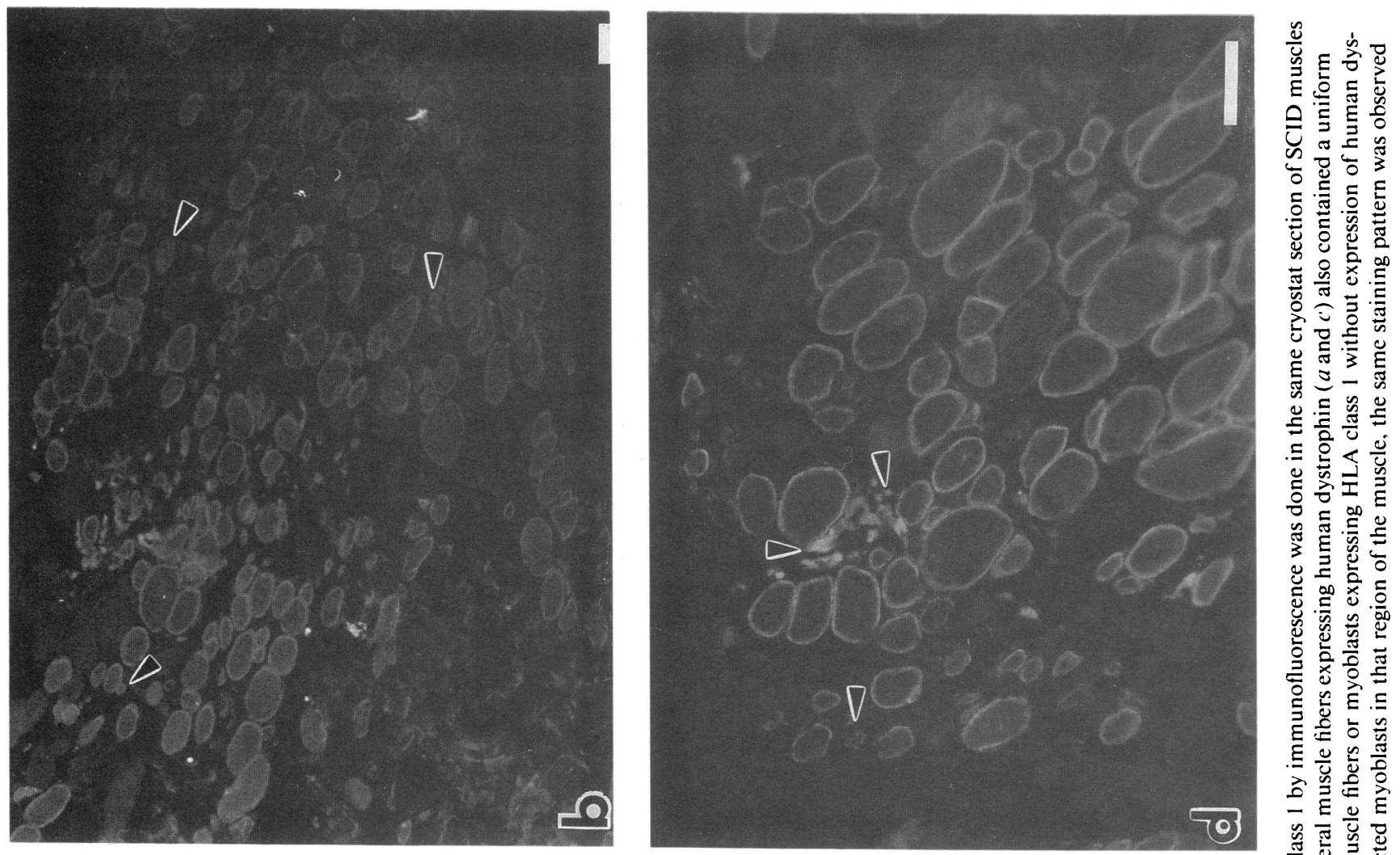

政

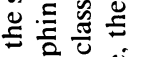

$\Xi$ 원 它究至

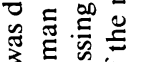
主航 ํㅣㄹ 论 훙

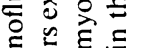

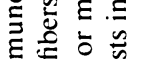
등

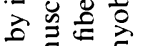
ज踏远

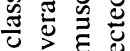
$\leq \tilde{\omega}=\overline{\bar{\Xi}}$ ㅊㅗㅎㅀ 흘 氖造

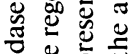

要 希总总

过

志导 焉 ते อ 흥 $\frac{5}{3}$

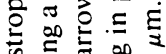

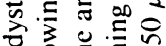

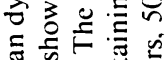

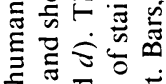

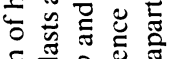

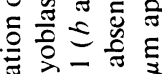
를 ชू 응 应宫 을 중 言吉气岛 $\wedge$. 


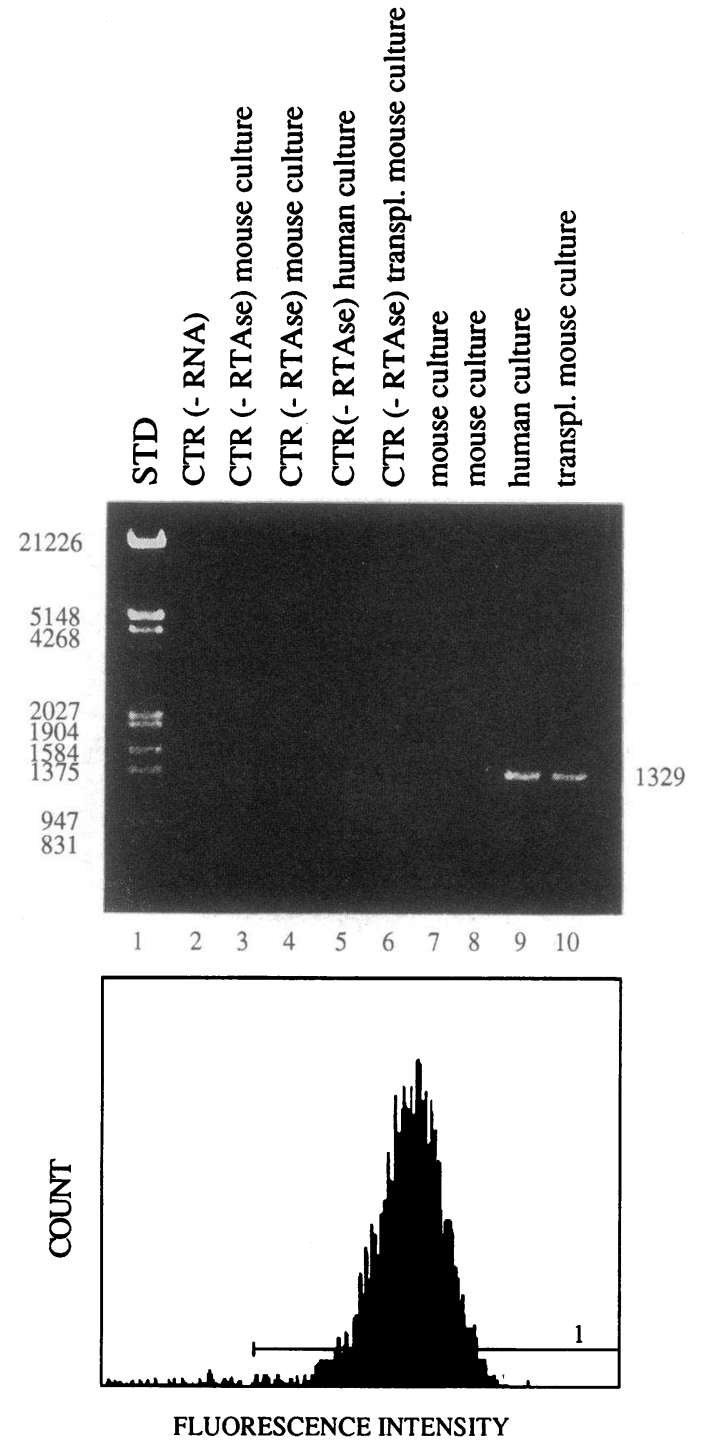

Figure 8. (a) Human dystrophin mRNA was detected by PCR amplification in human myoblast culture and in a culture from a mouse muscle transplanted with human myoblasts. The first lane contains molecular weight standards. The number of base pairs are written on the left. The second lane is a control that contained every reaction product except the RNA. In lanes 3-6, the reverse transcriptase has been omitted during amplification of RNA obtained from normal mouse myoblast and myotube cultures (lanes 3 and 4 ), from a culture of human myoblasts and myotubes (lane 5 ) and from a culture obtained from a SCID muscle previously transplanted with human myoblasts (lane 6). All these controls indicate that PCR amplification does not amplify dystrophin DNA. Lanes 7 and 8 are the reverse transcription (RT)-PCR amplification of RNA from a myoblast and myotube culture from a normal mouse muscle (not transplanted with human myoblasts). There is no amplification of mouse dystrophin mRNA. Lane 9 is the RT-PCR of RNA from a culture of human myoblasts and myotubes. The amplified human dystrophin mRNA fragment has a size of $1,329 \mathrm{bp}$. Lane 10 is the RT-PCR amplification of RNA from a myoblast and myotube culture obtained from a SCID muscle previously transplanted with human myoblasts. The human dystrophin mRNA present in the culture is amplified. ( $b$ ) Biopsies of muscles transplanted with human myoblasts clones were trypsinized and placed in culture. HLA class I was detected by flowcytometry using a specific antibody (W6/32) on $98 \%$ of the cells present in these cultures, indicating that they were human myoblasts. pressed HLA class 1 on their membranes. HLA class 1 has been previously reported to be present on muscle fibers during muscle regeneration and inflammatory process $(35,36)$. The high correlation between the presence of HLA class 1 and human dystrophin (Fig. 6) on muscle fibers is additional proof that these muscle fibers are produced by the fusion of human myoblasts. A few small profiles expressed the HLA class 1 but did not express human dystrophin. These profiles could be myoblasts or small myotubes. If they are myotubes, this suggests that HLA class 1 is expressed on the membrane before dystrophin or that HLA has a larger nuclear domain than dystrophin. It is important to note that detection of HLA permits to follow the fate of injected human myoblasts in mice.

In more completely regenerated muscle parts, HLA is expressed only in small cells. In some parts of a muscle that appeared more completely regenerated by the myoblast transplantations, although most of the muscle fibers expressed human dystrophin in their membranes, they did not express HLA class 1 . It is well known that HLA class 1 is not expressed in the membrane of normal mature human muscle fibers $(35,36)$. Although HLA class 1 was not expressed in the membranes of these muscle fibers, small cells positive for this antigen were present in close apposition with them. These small cells may be human myoblasts in the process of becoming satellite cells. This possibility is very important for the therapeutic application of myoblast transplantation. The final proof of this interpretation will require the demonstration by electron microscopy that the HLA-positive cells are located between the sarcolemma and the basal lamina. However, our experiments have clearly shown that human myoblasts can proliferate from a biopsy of a myoblast-injected muscle. The small HLA-positive cells present in muscle sections and biopsy cultures cannot be human fibroblasts because human myoblast clones (expressing the NCAM antigen not present on fibroblasts) were injected. Moreover, the cells present in muscle biopsy culture formed small myotubes expressing human dystrophin identified by PCR.

Possible hybrid muscle fibers. The colocalization of human dystrophin and mouse MHC antigen in only a few muscle fibers indicates that only a few regenerated muscle fibers are hybrid. Most of the muscle fibers expressing human dystrophin, therefore, result from the fusion of human myoblasts with each other. The hybrid muscle fibers may be formed by the fusion of human myoblasts with mouse fibers that have survived notexin treatment.

Presence of neuromuscular junctions. Some muscle fibers expressed dystrophin more strongly in a small segment of their sarcolemma. Such accumulation of dystrophin has been shown by us and others to be the site of $(a)$ cholinergic receptor accumulation, $(b)$ high cholinesterase activity, and $(c)$ desmin accumulation. These sites have, therefore, been interpreted as neuromuscular junctions (37-40). Therefore, we conclude the muscle fibers resulting from human myoblast transplantation are mature enough to be innervated.

No interpretation problem caused by back mutation. The combined detections of human dystrophin with NCLDys3 and human myoblasts with $\mathrm{W} 6 / 32$ provide excellent techniques to follow the fate of human myoblasts in xenograft experiments. Our technique completely avoids the problems of interpretation present in other studies, where normal mouse myoblasts are transplanted in mdx mice. Indeed, in these studies there is often an interpretation problem caused by the presence of re- 

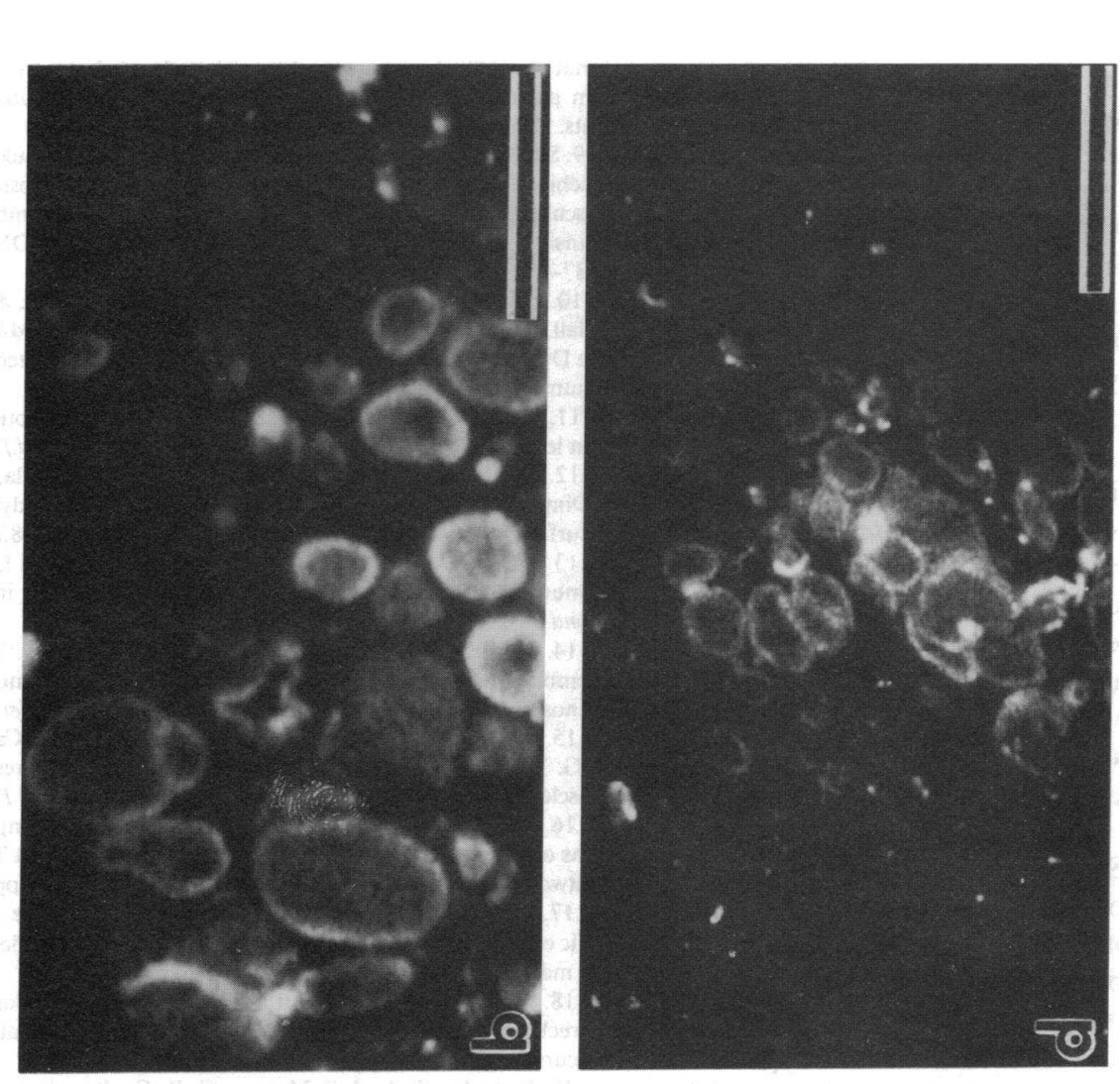

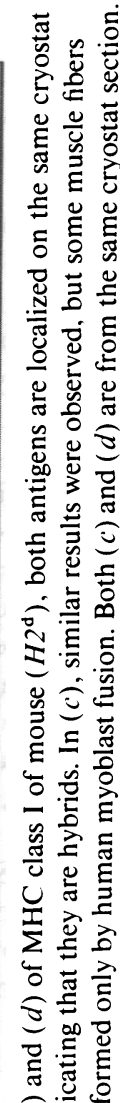
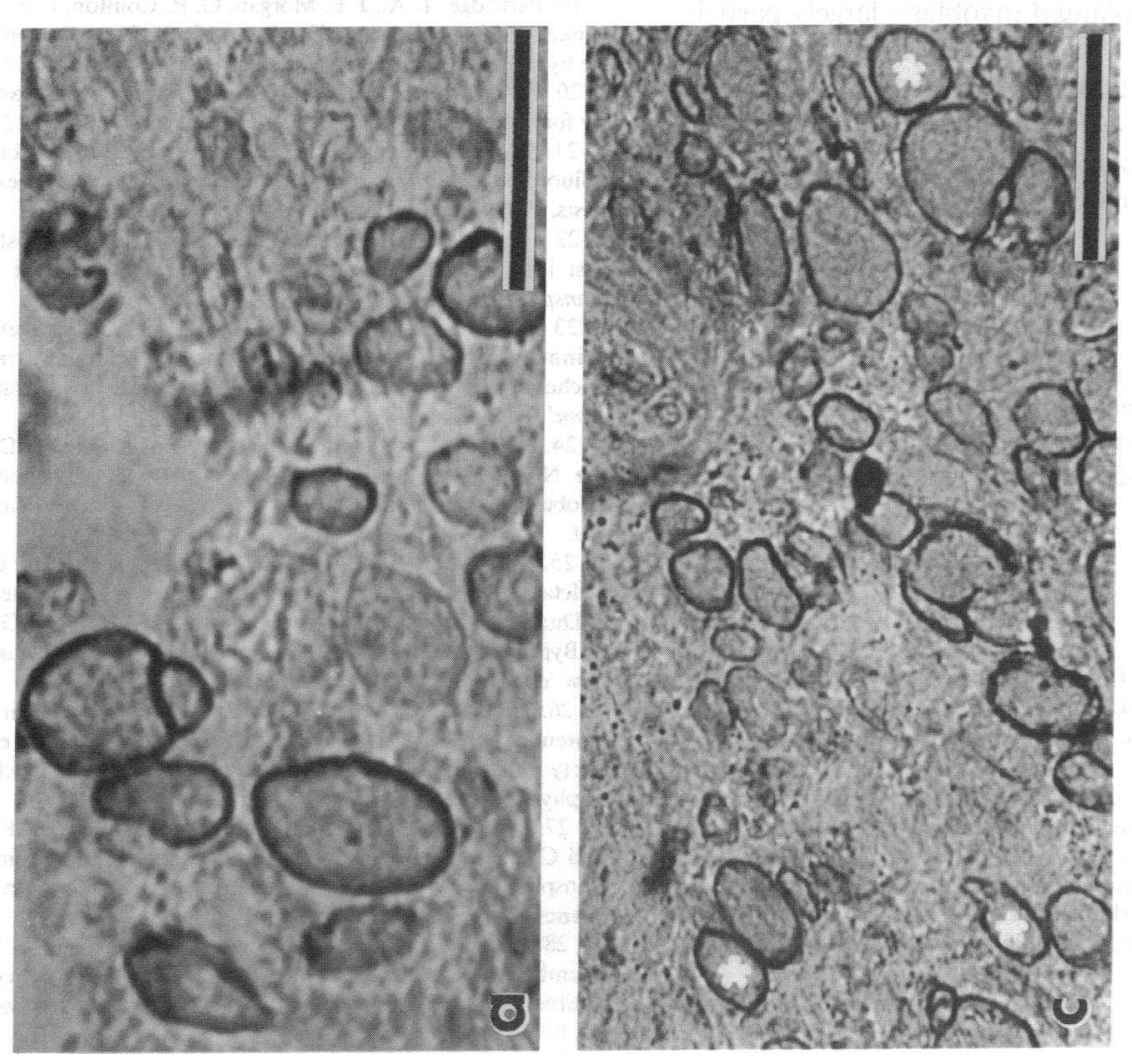

S.

$\Xi$ 远

空

会要

Z

总员.

등

흥 흥문

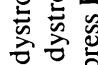

玄

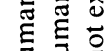

至至

$\leftarrow$

을

䨔

可 氕

宁帝

完造

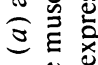

동 䆑

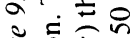

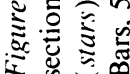


verse mutation in the $\mathrm{mdx}$ mice (41), since the dystrophin produced by the reverse mutation cannot be distinguished from the dystrophin produced by the transplanted normal mouse myoblasts. In our results, given the high specificity of the NCLDys 3 monoclonal antibody for human dystrophin (32), it is absolutely sure that the muscle fibers containing human dystrophin are produced by the transplanted myoblasts. These results clearly show that myoblast transplantation in immunodeficient mice is a good treatment to regenerate muscle fibers in a damaged muscle that has little or no endogenous regenerative capacity. Further investigations are underway to obtain similar results in mdx mice treated with an adequate sustained immunosuppression.

Intense proliferation of myoblasts does not produce rabdomyosarcoma. It is also clear from our results that long-term culture of human myoblasts does not result in a loss of their ability to differentiate and form myofibers. Recently, some concern has been raised $(42,43)$ that the intense proliferation of myoblasts in tissue culture could transform the cells, causing tumors. Our laboratory has developed an in vitro test based on proliferation in soft agar to verify whether a myoblast clone is tumorigenic (44). We have, in the past, observed some suspicious clones growing in soft agar, but we have not yet demonstrated the formation of a rabdomyosarcoma in vivo. In the present series of experiments, a pool of 20 myoblast clones has been used to produce more than 200 million myoblasts for transplantation in nude and SCID mice, we have not observed any evidence of the formation of rhabdomyosarcomas. Such rhabdomyosarcomas were obtained by Wernig et al. (43) using a permanent cell line, not a primary culture.

Our results clearly show that when myoblast transplantations are done in an immunodeficient SCID mice to bypass the immune problems, the transplanted myoblasts largely participate to muscle regeneration. This high level of participation to muscle regeneration was obtained even when each clone of human myoblasts had been grown to produce more than 10 million myoblasts each. Both observations support the potential treatment of DMD patients with myoblast injections.

\section{Acknowledgments}

We wish to thank Ms. Lyse Laroche for her secretarial assistance, and Ms. Brigitte Roy and Ms. Marlyne Goulet for their technical assistance.

This experimental work was supported by grants from the Medical Research Council of Canada and Muscular Dystrophy Association of Canada.

\section{References}

1. Ray, P. N., B. Belfall, C. Duff, C. Logan, V. Kean, M. W. Thompson, J. E. Sylvester, J. L. Gorski, R. D. Schmickel, and R. G. Worton. 1985. Cloning of the breakpoint of an $\mathrm{Xp} 21$ translocation associated with Duchenne dystrophy. $\mathrm{Na}$ ture (Lond.). 318:672-675.

2. Monaco, A. P., R. L. Neve, C. Colletti-Feener, C. J. Bertelson, D. M. Kurnit, and L. M. Kunkel. 1986. Isolation of candidate cDNAs for portions of the Duchenne muscular dystrophy gene. Nature (Lond.). 323:646-650.

3. Arahata, E., S. Ishiura, T. Ishiguro, T. Tsukahara, Y. Suhara, C. Eguchi, T. Ishihara, I. Nonaka, E. Ozawa, and H. Sugita. 1988. Immunostaining of skeletal and cardiac muscle surface membrane with antibody against Duchenne muscular dystrophy peptide. Nature (Lond.). 333:861-863.

4. Beam, K. G. 1988. Duchenne muscular dystrophy: localizing the gene product. Nature (Lond.). 333:798-799.

5. Bonilla, E., C. E. Samitt, A. F. Miranda, A. P. Hays, G. Salviati, S. Dimauro, L. M. Kunkel, E. P. Hoffman, and L. P. Rowland. 1988. Duchenne muscular dystrophy: deficiency of dystrophin at the muscle cell surface. Cell. $54: 447-452$.
6. Hoffman, E. P., M. S. Hudecki, P. A. Rosenberg, C. M. Pollina, and L. M. Kunkel. 1988. Cell and fiber-type distribution of dystrophin. Neuron. 1:411-420.

7. Hoffman, E. P., C. M. Knudson, R. P. Campbell, and L. M. Kunkel. 1987. Subcellular fractionation of dystrophin to the triads of skeletal muscle. Nature (Lond.). 330:754-758.

8. Miranda, A. F., E. Bonilla, G. Mastucci, C. T. Moraes, A. P. Hays, and S. Dimauro. 1988. Immunocytochemical study of dystrophin in muscle culture from patients with Duchenne muscular dystrophy and unaffected control patients. Am. J. Pathol. 132:410-416.

9. Sugita, H., K. Arahata, T. Ishiguro, Y. Suhara, T. Tsukahara, J. Ishiura, C. Eguchi, I. Nonaka, and E. Ozawa. 1988. Negative immunostaining of Duchenne muscular dystrophy (DMD) and mdx muscle surface membrane with antibody against synthetic peptide fragment predicted from DMD cDNA. Proc. Jpn. Acad. 64:37-39.

10. Zubrzycka-Gaarn, E. E., D. E. Bulman, G. Karpati, A. H. M. Burghes, B. Belfall, H. J. Klamut, J. Talbot, R. S. Hodges, P. N. Ray, and R. G. Worton. 1988. The Duchenne muscular dystrophy gene product is localized in the sarcolemma of human skeletal muscle. Nature (Lond.). 333:466-469.

11. Menke, A., and H. Jockush. 1991. Decreased osmotic stability of dystrophin less muscle cells from the mdx mouse. Nature (Lond.). 349:69-71.

12. Salviati, G., R. Betto, S. Geoldo, E. Biasia, E. Bonilla, A. F. Miranda, and S. Dimauro. 1989. Cell fractionation studies indicate that dystrophin is a protein of surface membrane of skeletal muscle. Biochem. J. 258:837-841.

13. Watkins, S. C., E. P. Hoffman, H. S. Slayter, and L. M. Kunkel. 1988. Immunoelectron microscopic localization of dystrophin in myofibres. Nature (Lond.). 333:863-866.

14. Huard, J., R. Roy, B. Guérette, S. Verreault, G. Tremblay, and J. P. Tremblay. 1994. Human myoblast transplantation in immunodeficient and immunosuppressed mice: evidence of rejection. Muscle \& Nerve. In press.

15. Karpati, G., Y. Pouliot, E. Zubrzycka-Gaarn, S. Carpenter, P. N. Ray, R. G. Worton, and P. Holland. 1989. Dystrophin is expressed in mdx skeletal muscle fibers after normal myoblast implantation. Am. J. Pathol. 135:27-32.

16. Morgan, J. E. 1990. Practical aspects of myoblast implantation: investigations of two inherited myopathies in animals. In Myoblast Transfer Therapy. A. Eastwood, G. Karpati, and R. Griggs, editors. New York pp. 89-96.

17. Morgan, J. E., E. P. Hoffman, and T. A. Partridge. 1990. Normal myogenic cells from newborn mice restore normal histology to degenerating muscle of the mdx mouse. J. Cell Biol. 111:2437-2449.

18. Morgan, J. E., D. J. Watt, J. C. Sloper, and J. A. Partridge. 1988. Partial correction of an inherited defect of skeletal muscle by grafts of normal muscle precursor cells. J. Neurol. Sci. 86:137-147.

19. Partridge, T. A., J. E. Morgan, G. R. Coulton, E. P. Hoffman, and L. M. Kunkel. 1989. Conversion of $\mathrm{mdx}$ myofibers from dystrophin negative to positive by injection of normal myoblasts. Nature (Lond.). 337:176-179.

20. Partridge, T. A. 1991. Invited review: myoblasts transfer, a possible therapy for unherited myopathies. Muscle \& Nerve 14:197-212.

21. Satoh, A., J. Huard, C. Labrecque, and J. P. Tremblay. 1993. Utilization of fluorescent latex microspheres (FLMs) to follow the fate of transplanted myoblasts. J. Histochem. Cytochem. 41:1579-1582.

22. Law, P. K., T. G. Goodwin, and H. J. Li. 1988. Histoincompatible myoblast injection improves muscle structure and function of dystrophic mice. Transp. Proc. XX:1114-1119.

23. Gussoni, E., G. K. Pavlath, A. M. Lanctot, K. Sharma, R. G. Miller, L. Steinman, and H. M. Blau. 1992. Normal dystrophin transcripts detected in Duchenne muscular dystrophy patients after myoblast transplantation. Nature (Lond.). 356:435-438.

24. Huard, J., J. P. Bouchard, R. Roy, F. Malouin, G. Dansereau, C. Labrecque, N. Albert, C. L. Richards, B. Lemieux, and J. P. Tremblay. 1992. Human myoblast transplantation: preliminary results of 4 cases. Muscle \& Nerve. 15:550560.

25. Karpati, G. 1992. Approaches to the introduction of normal alleles into skeletal muscle fibers for therapeutic purposes in Duchenne muscular dystrophy. In Duchenne Muscular Dystrophy: Animals Models and Genetic Manipulation. A. Byron, J. Kakulas, A. MacHawell, and D. Rosen, editors. Raven Press Ltd., New York. pp. 223-236.

26. Law, P. K., T. G. Goodwin, Q. Fang, V. Duggirala, C. Larkin, J. A. Florendo, D. S. Kirby, M. B. Deering, H. Li, and M. Chen, et al. 1992. Feasibility, safety and efficacy of myoblast transfer therapy on Duchenne muscular dystrophy boys. Cell Transplant. 1:235-244.

27. Tremblay, J. P., F. Malouin, R. Roy, J. Huard, J. P. Bouchard, A. Satoh, and C. L. Richards. 1993. Results of a triple blind clinical study of myoblast transplantations without immunosuppressive treatment in young boys with Duchenne muscular dystrophy. Cell Transplant. 2:99-112.

28. Huard, J., R. Roy, J. P. Bouchard, F. Malouin, C. L. Richards, and J. P. Tremblay. 1992. Human myoblast transplantations between immunohistocompatible donors and recipients produce immune reactions. Transplant Proc. 24:3049-3051.

29. Ham, R. G., J. A. St. Clair, C. Webster, and H. M. Blau. 1988. Improved media for normal human muscle satellite cells: serum free clonal growth and enhanced growth with no serum. In Vitro Cell. \& Dev. Biol. 24:833-844.

30. Yasin, R., G. Van Beers, K. C. E. Nurse, S. Alani, D. N. London, and E. J. 
Thompson. 1977. A quantitative technique for growing human adult skeletal muscle in culture starting from mononucleated cells. J. Neurol. Sci. 32:347-360

31. Harris, J. B., and M. A. Johnson. 1978. Further observations on the pathological responses of rat skeletal muscle to toxins isolated from the venom of the australian tiger snake notechis scutatus scutatus. Clin. Exp. Pharmacol. Physiol. 5:587.

32. Huard, J., J. P. Tremblay, S. Verreault, C. Labrecque, and J. P. Tremblay. 1993. Utilization of an antibody specific for human dystrophin to follow myoblast transplantation in nude mice. Cell Transplantation. 2:113-118.

33. Chomczynski, P., and N. Sacchi. 1987. Single-step method of RNA isolation by acid guanidinium thiocyanate-phenol-chloroform extraction. Anal. Bio chem. 162:156-159.

34. Roberts, R., T. F. M. Barby, E. Manners, M. Bobrow, and D. R. Bentley 1991. Direct detection of dystrophin gene rearrangements by analysis of dystrophin mRNA in peripheral blood lymphocytes. Am. J. Hum. Genet. 49:298-310.

35. Emslie-Smith, A. M., K. Arahata, and A. G. Engel. 1989. Major histocompatibility complex class I antigen expression, immunolocalization of interferon subtypes and T-cell-mediated cytotoxicity in myopathies. Hum. Pathol. 20:224231.

36. Karpati, G., Y. Pouliot, and S. Carpenter. 1988. Expression of immunoreactive major histocompability complex product in human skeletal muscles. Ann Neurol. 23:64-72.

37. Huard, J., L. P. Fortier, C. Labrecque, G. Dansereau, and J. P. Tremblay.
1992. A light and electron microscopic study of dystrophic localization at the mouse neuromuscular junction. Synapse (NY). 10:83-93.

38. Huard, J., L. P. Fortier, C. Labrecque, G. Dansereau, and J. P. Tremblay. 1991. Is dystrophin present in the nerve terminal at the neuromuscular junction An immunohistochemical study of the heterozygote $(\mathrm{mdx})$ mouse. Synapse (NY). 7:135-140.

39. Miike, T., M. Miyatake, J. Zhao, K. Yoshioka, and M. Uchino. 1989. Immunohistochemical dystrophin reaction in synaptic regions. Brain \& Dev. 11:344-346.

40. Shimizu, T., K. Matsumura, Y. Sunada, and T. Mannen. 1989. Dense immunostaining on both neuromuscular and myotendon junctions on both neuromuscular and myotendon junctions with an antidystrophin monoclonal antibody. Biomed. Res. 10:405-409.

41. Hoffman, E. P., J. E. Morgan, S. C. Watkins, and T. A. Partridge. 1990. Somatic reversion suppression of the mouse $\mathrm{mdx}$ phenotype in vivo. J. Neurol. Sci. 99:9-25.

42. Hoffman, E. 1993. Myoblast transplantation: what's going on? Cell Transplant. 2:49-57.

43. Wernig, A., A. Irintchev, A. Hartling, G. Stephan, K. Zimmermann, and A. Starzinski-Powitz. 1991. Formation of new muscle fibers and tumours after injection of culture myogenic cells. J. Neurocytol. 20:982-997.

44. Tremblay, J. P., B. Roy, and M. Goulet. 1991. Human myoblast transplantation: a simple assay for tumorigenicity. Neuromusc. Disorders. 5:341-343. 